\title{
EXPLAINING MOBILE COMMERCE USAGE INTENTION BASED ON TECHNOLOGY ACCEPTANCE MODELS IN A DEVELOPING MARKET CONTEXT
}

\author{
OBJAŠNJENJE NAMJERE KORIŠTENJA \\ MOBILNE TRGOVINE NA TEMELJU \\ MODELA PRIHVAĆANJA TEHNOLOGIJE \\ (TAM) U OKVIRU TRŽIŠTA U RAZVOJU
}

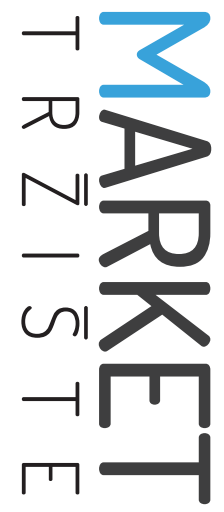

Market-Tržište

Vol. 33, No. 1, 2021, pp. 25-40

UDK 004.738.5:621.395.721.5:339

DOI http://dx.doi.org/10.22598/mt/2021.33.1.25

Preliminary communication

\section{Luis Edwin Chimborazo ${ }^{a}$, Marta Frasquet ${ }^{b}$, Alejandro Mollác \\ aUniversity of Valencia, Marketing Department, Av Tarongers s/n, 46022 Valencia, SPAIN, e-mail: luischim@alumni.uv.es bUniversity of Valencia, Marketing Department, Av Tarongers s/n, 46022 Valencia, SPAIN, e-mail: marta.frasquet@uv.es 'University of Valencia, Marketing Department, Av Tarongers s/n, 46022 Valencia, SPAIN, e-mail: alejandro.molla@uv.es}

\begin{abstract}
Purpose - This paper aims to explain the intention to use mobile phones for shopping based on the technology acceptance model (TAM) and the unified theory of acceptance and use of technology (UTAUT2) model in a developing country context, characterized by the mobile channel's high growth rates. The research model analyzes perceived usefulness, perceived ease of use, social influence, facilitating conditions, and hedonic motivation on $\mathrm{m}$-commerce usage intention.
\end{abstract}

Design/Methodology/Approach - Data for the research were collected through a survey among mobile commerce users in Ecuador. We tested the model through partial least squares structural equations modeling (PLS-SEM).

Findings and implications - The results showed that social influence, facilitating conditions, and hedonic motivation are significant determinants of the intention to use mobile commerce in a developing market context, while perceived usefulness and perceived ease of use

\section{Sažetak}

Svrha - Radom se nastoji objasniti namjera korištenja mobilnih telefona za kupovinu temeljem modela TAM i UTAUT2 u okviru zemlje u razvoju za koju su karakteristične visoke stope rasta mobilnih kanala. Istraživački model analizira percipiranu korisnost, lakoću korištenja, društveni utjecaj, uvjete i hedonističku motivaciju namjere korištenja mobilne trgovine.

Metodološki pristup - Podatci su prikupljeni anketiranjem korisnika mobilne trgovine u Ekvadoru. Model je testiran modeliranjem strukturnih jednadžbi metodom parcijalnih najmanjih kvadrata (PLS-SEM).

Rezultati i implikacije - Rezultati su pokazali da su društveni utjecaj, uvjeti i hedonistička motivacija značajne odrednice namjere korištenja mobilne trgovine u okviru tržišta u razvoju, a percipirana korisnost i percipirana lakoća korištenja nisu. Glavni doprinos rada jest pokazati da kada se TAM model proširi uključivanjem varijabli modela UTAUT2 koji se preciznije odnose na mobilno okruženje, utjecaj varijabli jednostavnosti 
are not. This paper's main contribution consists in showing that, when the TAM model is expanded by including variables of the UTAUT 2 model relating more specifically to the mobile technology, the influence of the ease-ofuse and usefulness variables is not significant. Companies could develop mobile interfaces that are pleasant and stimulating, rather than utilitarian, since hedonic motivation is the variable with the greatest influence on $\mathrm{m}$-commerce intention, and the one that emphasizes the social aspect of $\mathrm{m}$-commerce.

Limitations - The sample included individuals from a single country who were recruited from a university.

Originality - The study focuses on m-commerce usage in a Latin American country, based on a combined TAM-UTAUT2 model that includes variables capturing the technological and social aspects of $\mathrm{m}$-commerce.

Keywords - TAM model, UTAUT2 model, mobile commerce, developing market uporabe i korisnosti nije značajan. Menadžeri bi mogli razviti mobilna sučelja koja su ugodna i poticajna, a ne utilitaristička, jer je hedonistička motivacija varijabla koja najviše utječe na namjeru $\mathrm{m}$-trgovine $\mathrm{i}$ ističe njezin društveni aspekt.

Ograničenja - U uzorak su uključeni ispitanici iz samo jedne zemlje s jednog sveučilišta.

Doprinos - Autori proučavaju korištenje m-trgovine u latinoameričkoj zemlji na temelju kombiniranog TAMUTAUT2 modela koji uključuje varijable koje obuhvaćaju tehnološke i društvene aspekte $m$-trgovine.

Ključne riječi - TAM model, UTAUT2 model, mobilna trgovina, tržište u razvoju 


\section{INTRODUCTION}

The increasing possession of smartphones around the globe has brought about significant transformations in society and the economy, with the growth of mobile commerce (m-commerce) being one of them (Anwar, Thongpapanl \& Ashraf, 2020). Mobile phones offer great potential as marketing channels, especially in emerging markets (Aslam, Ham \& Arif, 2017). According to the PwC Global Survey (PWC, 2019), mobile sales have doubled since 2015, reaching 24\% of consumers in 2019 and, for the first time, surpassing the PC channel.

Mobile commerce can be understood as an extension of e-commerce where commercial transactions are conducted through a mobile device using a wireless network (Chhonker, Verma \& Kar, 2017; Zhang, Zhu \& Liu, 2012). However, m-commerce should be considered a new channel for commercial transactions, since it integrates additional capabilities that allow retailers to provide specific services to mobile users (Chhonker et al., 2017; Kleijnen, de Ruyter \& Wetzels, 2007; Ström, Vendel \& Bredican, 2014). M-commerce offers advantages to users, such as the ability to customize and access its platforms at any time and place (Chong, Chan \& Ooi, 2012; Thakur \& Srivastava, 2013). Research has also shown that users encounter technical limitations when using smartphones for shopping (Wang, Malthouse \& Krishnamurthi, 2015; Zhou, 2013). However, recent advances in connectivity and smartphone usability are eliminating users' reluctance to use $\mathrm{m}$-commerce.

A literature review on m-commerce revealed the need for further research of the manner in which mobile devices influence the buying process (Choi, 2018; Shankar, Kleijnen, Ramanathan, Rizley, Holland \& Morrissey, 2016). Numerous studies have predicted the intentions of consumers to make purchases through mobile devices. However, there is insufficient knowledge of the factors affecting m-commerce usage in developing countries. Developing countries show surging rates of smartphone penetration that trigger rapid changes in consumer behavior. The development of the mobile channel is an opportunity for domestic enterprises investing in this channel to gain customer loyalty and compete with global players (Ntsafack Dongmo, Kala Damdjoug \& Fosso Wamba, 2020). Among developing regions, Latin America is the fastest-growing m-commerce market worldwide, ahead of Asia and Africa (eMarketer, 2019). This paper focuses on Ecuador, where smartphone possession rose from 53.9\% in 2014 to $75.3 \%$ in 2019 . Sales through mobile devices reached USD 221.3 in 2019, growing at a yearly rate of $48 \%$ since 2014 . More growth is expected in the coming years, with mobile phones being the fastest-growing retail channel in Ecuador (Euromonitor, 2020).

A number of studies on m-commerce usage in developing countries have been published in recent years. Most research (e.g., Anwar et al., 2020; Assarut \& Eiamkanchanalai, 2015; Chong et al., 2012; Madan \& Yadav, 2018; Thakur \& Srivastava, 2013; Wei, Marthandan, Chong, Ooi \& Arumugam, 2009; Yadav, Sharma \& Tarhini, 2016) has focused on Asian markets, with Middle East (Alalwan, Dwivedi, Rana, Lal \& Williams, 2015; Aslam et al., 2017; Faqih \& Jaradat, 2015; Tarhini, Alalwan, Shammout \& Al-Badi, 2019) and African markets receiving some attention (Ntsafack Dongmo et al., 2020; Verkijika, 2018). Despite its size and substantial m-commerce growth, the Latin American region has been less studied; however, some exceptions include a study conducted by Jiménez San-Martin and Azuela (2016) on the Mexican market and that by Marinao-Artigas and Barajas-Portas (2020). The present study attempts to fill the research gap on $\mathrm{m}$-commerce usage in developing countries by testing a model based on technology acceptance (TAM) and the unified theory of acceptance and use of technology (UTAUT2) (Davis, 1989; Venkatesh, Thong \& Xu, 2012) in Ecuador. Our research proposal includes the key TAM variables of perceived usefulness and perceived ease of use, and three variables proposed by the UTAUT2, namely, social influence, facilitating

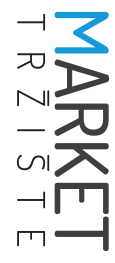


conditions, and hedonic motivation, in line with the recommendation of Lu (2014) to expand the TAM by taking into consideration the specific context of m-commerce through smartphones. Thus, we aim to empirically identify the factors influencing the intention to use $\mathrm{m}$-commerce in Ecuador, where the mobile channel shows high growth potential. This paper contributes to the literature by analyzing $\mathrm{m}$-commerce usage in developing countries with high growth rates, and does so through a model which includes the variables of technology adoption models that are more relevant in the context of smartphone usage.

This paper is structured as follows: The introduction is followed by a literature review of the literature. Then, the research hypotheses are justified, and the research model of $\mathrm{m}$-commerce usage intention is presented. The methodology used to collect and analyze the data is described, followed by an analysis of the results. Finally, the main conclusions of the study are presented, highlighting the implications and limitations of the research and identifying lines for future research.

\section{LITERATURE REVIEW}

M-commerce has been defined as a monetary transaction conducted through a mobile communications network (Okazaki, 2005). Smartphones are seen as a marketing channel that consumers can use anywhere and are, therefore, an extension of a store or brand in people's pockets. Compared to e-commerce, m-commerce presents new opportunities due to its benefits of mobility, savings in terms of time and money, comfort, convenience, and accessibility (Wei et al., 2009; Zhang, Chen \& Lee, 2013). At the same time, the use of mobile devices offers companies advantages such as cost reductions, real-time tracking of customers' activities and the ability to influence people through contextual offers adapted to their mobile devices (Larivière, Joosten, Malthouse, van Birgelen, Aksoy, Kunz \& Huang, 2013). Thus, m-commerce consti- tutes a new marketing channel that allows consumers a new way of interacting with retailers, brands, and other consumers at any time and in any place (Andrews, Goehring, Hui, Pancras \& Thornswood, 2016; Shankar, Venkatesh, Hofacker \& Naik, 2010).

Research on the adoption or use of m-commerce by consumers continues to arouse great interest with a view to clarifying the factors that prompt consumers to shop or not to shop using their smartphones. In this regard, special mention should be made of the studies that have applied technology acceptance theories or models, such as TAM (Davis, 1989), UTAUT (Venkatesh, Morris, Davis \& Davis, 2003), or innovation diffusion theory (IDT) (Rogers, 1983). A summary of the studies applying TAMs to explain the adoption or use of $\mathrm{m}$-commerce by consumers is presented in Table 1.

TABLE 1: Synthesis of empirical m-commerce studies based on TAMs

\begin{tabular}{|c|c|c|c|}
\hline $\begin{array}{c}\text { Author(s) } \\
\text { (year) }\end{array}$ & $\begin{array}{l}\text { Under- } \\
\text { lying } \\
\text { theories }\end{array}$ & $\begin{array}{l}\text { Variables } \\
\text { employed }\end{array}$ & Context \\
\hline $\begin{array}{l}\text { Bhatti } \\
(2007)\end{array}$ & $\begin{array}{l}\text { TAM, TPB, } \\
\text { TRA, DOI }\end{array}$ & $\begin{array}{l}\text { perceived usefulness } \\
\text { ease of use } \\
\text { personal } \\
\text { innovativeness }\end{array}$ & $\begin{array}{l}\text { United } \\
\text { Arab } \\
\text { Emirates }\end{array}$ \\
\hline $\begin{array}{l}\text { Wei et al. } \\
\text { (2009) }\end{array}$ & TAM & $\begin{array}{l}\text { perceived usefulness } \\
\text { perceived ease of use } \\
\text { social influence } \\
\text { trust } \\
\text { perceived cost }\end{array}$ & China \\
\hline $\begin{array}{l}\text { Yang } \\
(2010)\end{array}$ & UTAUT2 & $\begin{array}{l}\text { social influence } \\
\text { facilitating conditions } \\
\text { attitude } \\
\text { utilitarian } \\
\text { performance } \\
\text { expectancy } \\
\text { hedonic performance } \\
\text { expectancy } \\
\text { effort expectancy }\end{array}$ & $\begin{array}{l}\text { United } \\
\text { States of } \\
\text { America } \\
\text { (USA) }\end{array}$ \\
\hline $\begin{array}{l}\text { Zhang et } \\
\text { al. (2012) }\end{array}$ & TAM, TRA & $\begin{array}{l}\text { perceived usefulness } \\
\text { perceived ease of use } \\
\text { innovativeness } \\
\text { perceived cost } \\
\text { attitude } \\
\text { trust } \\
\text { perceived risk } \\
\text { perceived enjoyment }\end{array}$ & $\begin{array}{l}\text { Meta- } \\
\text { analysis }\end{array}$ \\
\hline
\end{tabular}




\begin{tabular}{|c|c|c|c|}
\hline $\begin{array}{c}\text { Author(s) } \\
\text { (year) }\end{array}$ & $\begin{array}{l}\text { Under- } \\
\text { lying } \\
\text { theories }\end{array}$ & $\begin{array}{l}\text { Variables } \\
\text { employed }\end{array}$ & Context \\
\hline $\begin{array}{l}\text { Chong et } \\
\text { al. (2012) }\end{array}$ & TAM, DOI & $\begin{array}{l}\text { perceived usefulness } \\
\text { perceived ease of use } \\
\text { social influence } \\
\text { trust } \\
\text { cost } \\
\text { variety of services }\end{array}$ & $\begin{array}{l}\text { China } \\
\text { and } \\
\text { Malaysia }\end{array}$ \\
\hline $\begin{array}{l}\text { Chong } \\
\text { (2013) }\end{array}$ & TAM & $\begin{array}{l}\text { perceived usefulness } \\
\text { perceived ease of use } \\
\text { perceived enjoyment } \\
\text { trust } \\
\text { cost }\end{array}$ & China \\
\hline $\begin{array}{l}\text { Thakur } \\
\text { and } \\
\text { Srivastava } \\
\text { (2013) }\end{array}$ & TAM, TAR & $\begin{array}{l}\text { perceived usefulness } \\
\text { perceived ease of use } \\
\text { social influence } \\
\text { facilitating conditions }\end{array}$ & India \\
\hline $\begin{array}{l}\text { Yang and } \\
\text { Forney } \\
\text { (2013) }\end{array}$ & UTAUT & $\begin{array}{l}\text { facilitating conditions } \\
\text { utilitarian } \\
\text { performance } \\
\text { expectancy } \\
\text { hedonic } \\
\text { performance } \\
\text { expectancy } \\
\text { social influence }\end{array}$ & USA \\
\hline Lu (2014) & TAM & $\begin{array}{l}\text { perceived usefulness } \\
\text { perceived ease of use } \\
\text { social influence }\end{array}$ & USA \\
\hline $\begin{array}{l}\text { Faqih and } \\
\text { Jaradat } \\
(2015)\end{array}$ & TAM & $\begin{array}{l}\text { perceived usefulness } \\
\text { perceived ease of use } \\
\text { subjective norm }\end{array}$ & Jordan \\
\hline $\begin{array}{l}\text { Yadav, } \\
\text { Sharma, } \\
\text { and } \\
\text { Tarhini } \\
\text { (2016) }\end{array}$ & $\begin{array}{l}\text { TAM, TPB, } \\
\text { IDT }\end{array}$ & $\begin{array}{l}\text { perceived usefulness } \\
\text { perceived ease of use } \\
\text { social influence } \\
\text { perceived cost } \\
\text { perceived trust }\end{array}$ & India \\
\hline $\begin{array}{l}\text { Marin- } \\
\text { kovic and } \\
\text { Kalinic } \\
(2017)\end{array}$ & TAM & $\begin{array}{l}\text { perceived usefulness } \\
\text { social influence } \\
\text { trust } \\
\text { mobility } \\
\text { perceived } \\
\text { enjoyment } \\
\text { customization }\end{array}$ & Serbia \\
\hline $\begin{array}{l}\text { Blaise et al. } \\
(2018)\end{array}$ & UTAUT & $\begin{array}{l}\text { social influence } \\
\text { facilitating conditions } \\
\text { performance } \\
\text { expectancy } \\
\text { effort expectancy }\end{array}$ & USA \\
\hline $\begin{array}{l}\text { Choi } \\
(2018)\end{array}$ & TAM & $\begin{array}{l}\text { perceived usefulness } \\
\text { ease of use } \\
\text { service ubiquity } \\
\text { location-based } \\
\text { service } \\
\text { user control }\end{array}$ & Korea \\
\hline
\end{tabular}

\begin{tabular}{|c|c|c|c|}
\hline $\begin{array}{c}\text { Author(s) } \\
\text { (year) }\end{array}$ & $\begin{array}{l}\text { Under- } \\
\text { lying } \\
\text { theories }\end{array}$ & $\begin{array}{l}\text { Variables } \\
\text { employed }\end{array}$ & Context \\
\hline $\begin{array}{l}\text { Madan } \\
\text { and Yadav } \\
\text { (2018) }\end{array}$ & UTAUT & $\begin{array}{l}\text { hedonic motivation } \\
\text { perceived critical } \\
\text { mass } \\
\text { perceived risk } \\
\text { facilitating conditions } \\
\text { perceived regulatory } \\
\text { support } \\
\text { cost }\end{array}$ & India \\
\hline $\begin{array}{l}\text { Verkijika } \\
\text { (2018) }\end{array}$ & UTAUT2 & $\begin{array}{l}\text { performance } \\
\text { expectancy } \\
\text { effort expectancy } \\
\text { social influence } \\
\text { facilitating conditions } \\
\text { hedonic motivation } \\
\text { price value } \\
\text { perceived risk } \\
\text { perceived trust }\end{array}$ & $\begin{array}{l}\text { Camer- } \\
\text { oon }\end{array}$ \\
\hline $\begin{array}{l}\text { Shaw and } \\
\text { Sergueeva } \\
\text { (2019) }\end{array}$ & UTAUT2 & $\begin{array}{l}\text { perceived value } \\
\text { social influence } \\
\text { facilitating conditions } \\
\text { hedonic motivation } \\
\text { habit } \\
\text { effort expectancy }\end{array}$ & Canada \\
\hline
\end{tabular}

Note: TAM=technology acceptance model; TRA=theory of reasoned action; $\mathrm{TPB}=$ theory of planned behavior; $\mathrm{DOI}=\mathrm{in}-$ novation diffusion theory; TAR=technology adoption readiness; IDT=innovation diffusion theory; UTAUT=unified theory of acceptance and use of technology.

One of the theoretical frameworks used in e-commerce research is the TAM model, proposed by Davis (1989) to better understand the adoption and continued use of a technology. TAM builds on the theory of reasoned action (TRA) by supposing that perceived usefulness and perceived ease of use are significant determinants of the use of a specific system or technology (Davis, Bagozzi \& Warshaw, 1989). The findings based on TAM to predict the intention to use a mobile phone for shopping support the importance of TAM's core variables, namely perceived usefulness and perceived ease of use. However, most studies include additional variables, together with the two original ones. Usefulness and ease of use are primary determinants, according to the results obtained by Choi (2018), who also found that the ubiquity of location-based services and user control contributed to a greater use of mobile phones for shopping. Marinkovic 
and Kalinic (2017) found that usefulness and ease of use are essential factors in the intention to use m-commerce in Serbia, together with social influence, trust, mobility, perceived enjoyment, and the moderating variable of customization. Other researchers reported that variables such as social influence, trust, perceived cost, and connectivity exert a positive influence on the use of $\mathrm{m}$-commerce in China (Chong et al., 2012; Wei et al., 2009). Therefore, to achieve a better understanding, it is necessary to expand the TAM, explicitly considering the context of smartphone-based $\mathrm{m}$-commerce $(\mathrm{Lu}, 2014)$. At this point, it is worthwhile considering the UTAUT model, which includes the following variables: performance expectancy, effort expectancy, social influence, and facilitating conditions. The authors of this model showed its superiority to the TAM and other user acceptance models (Venkatesh et al., 2003). Several studies in the m-commerce context have opted for the UTAUT model, validating the strength of its explanatory variables in the intention to use m-commerce (Blaise, Halloran \& Muchnick, 2018). For instance, Yang and Forney (2013) concluded that facilitating conditions include the main driver motivating consumers to conduct mobile shopping.

The UTAUT2 model is an extension of the UTAUT model incorporating the hedonic motivation variable (Venkatesh et al., 2012). The UTAUT2 model postulates that an element of enjoyment related to $\mathrm{m}$-commerce is associated with greater use of it (Shaw \& Sergueeva, 2019). Users make emotional decisions when deciding whether or not to use their mobile devices [for shopping] (Marinkovic \& Kalinic, 2017). Thus, hedonic motivation was revealed as a determining element in $\mathrm{m}$-commerce usage intention (Yang, 2010). Using the UTAUT2 model, Shaw and Sergueeva (2019) identified hedonic motivation and perceived value as the predominant variables in the intention to use m-commerce. Yang (2010) reported that social influence, facilitating conditions, effort expectancy, attitude, utilitarian performance expectancy, and hedonic performance are significant predictors in the $\mathrm{m}$-commerce usage intention.
As a conclusion of the literature review on consumer adoption or use of e-commerce, it can be observed that models based on extensions of the TAM are popular both in developed and developing markets. A smaller number of papers have adopted the UTAUT and UTAUT2 models, and only Verkijika (2018) has applied UTUAT2 to a developing market context. To the best of our knowledge, no study has modeled m-commerce adoption or use integrating the TAM and UTAUT2 variables that are most suitable for the mobile shopping context in a developing market.

\section{HYPOTHESES AND RESEARCH MODEL}

The TAM model provided the initial framework for our research model with its two key variables: perceived usefulness and perceived ease of use. Additionally, the extended UTAUT2 model based on the original UTAUT model was considered with its social influence, facilitating conditions, and hedonic motivation variables, which seem to be particularly suited to the mobile environment. The individual variables and the proposed logic underpinning each research hypothesis are defined below.

\section{Perceived usefulness}

Perceived usefulness was defined by Davis (1989, p. 320) as the "degree to which a person believes that using a particular system would enhance his or her job performance." Perceived usefulness has been found to significantly affect both the attitude towards technology and the intention to use (Davis et al., 1989; Venkatesh et al., 2003). Perceived usefulness in the adoption of mobile Internet focuses on the achievement of tasks and reflects an individual's desire to participate in an activity due to external rewards (Kim, Chan \& Gupta, 2007). Likewise, the review of the literature on mobile shopping (see Table 1) revealed that perceived usefulness is one of the variables more frequently considered by researchers to explain the adoption or use of m-commerce (Marinkovic \& Kalinic, 2017). The 
main advantage of $\mathrm{m}$-commerce over e-commerce via PC and cable connection is its ability to offer the service ubiquitously. Thus, as argued by Chong (2013), consumers will only use m-commerce if they find it more useful than e-commerce. Therefore, perceived usefulness is considered an important determinant of the intention to use m-commerce (Chong, 2013). Based on the above arguments, the first research hypothesis is proposed:

H1: Perceived usefulness positively influences $\mathrm{m}$-commerce usage intention.

\section{Perceived ease of use}

Perceived ease of use refers to the lack of effort required to use a technological system (Davis, 1989). Perceived ease of use is related to the innate characteristics of information technology, and its effect varies depending on whether the context is goal-oriented or hedonic (Davis, 1989; van der Heijden, 2004). Research revealed that perceived ease of use is not just an essential element in the adoption of technology; rather, it also affects the use of mobile devices for shopping (Choi, 2018). As argued by Assarut and Eiamkanchanalai (2015) and Wei and others (2009), consumers need to gain confidence and perceive the mobile channel as being easy to use before they are ready to use it for shopping. Thus, perceived ease of use is likely to have a positive influence on the consumers' intention to adopt m-commerce (Chong et al., 2012). Consequently, the following hypothesis was proposed:

H2: Perceived ease of use positively influences $\mathrm{m}$-commerce usage intention.

Relationship between ease of use and perceived usefulness

According to the TAM, perceived ease of use is a determinant of perceived usefulness; it may be claimed that systems that are easier to use ultimately become more useful (Davis, 1989). Ease of use has been identified as a predictive factor of perceived usefulness in mobile phone use (Lu, 2014). The perceived ease of use of mobile shopping technology has a key influence on per- ceived usefulness because consumers are able to interact easily on $\mathrm{m}$-commerce sites if they can understand their potential value better (Choi, 2018; Chong et al., 2012). Following this line of argument, the following hypothesis is proposed:

H3: Perceived ease of use has a positive effect on the perceived usefulness of $\mathrm{m}$-commerce.

\section{Social influence}

Social influence is defined as the degree to which the beliefs and opinions of others affect an individual's decision to adopt a new technological system (Venkatesh et al., 2003). Social influence is generated by different factors, such as informal influence, maintenance of social image, and critical mass (Wang \& Wang, 2010). For young consumers, image plays an important role in the decision to use a new device. To strengthen participation among group members, the user tends to adapt to the expectations of others (Bhatti, 2007).

Social influence in the context of m-commerce has been identified as a key variable for predicting m-commerce intention (Chong et al., 2012; Wei et al., 2009). Mobile devices are highly sensitive to social influence, since they are present in interactions in social environments with friends and family, which can influence the intention to use and adopt mobile technology (Blaise et al., 2018). In the m-commerce context, users are easily swayed by social influence and set new trends in m-commerce (Yadav et al., 2016). Therefore, we formulated the following hypothesis:

$\mathrm{H} 4$ : Social influence positively influences m-commerce usage intention.

\section{Facilitating conditions}

In the use of a technological system, factors such as conceptualized knowledge, technical resources, and other opportunities facilitate the tasks to be performed (Venkatesh, 2000). Facilitating conditions refer to the "degree to which an individual believes that an organizational and technical infrastructure exists to support use of the system" (Venkatesh et al., 2003, p. 453). Facili-

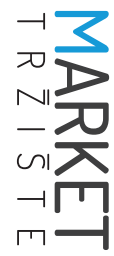


tating conditions provide the external resources required to achieve the performance of a particular behavior easily (Ajzen, 1991). Likewise, facilitating conditions coupled with behavioral intention are the factors influencing user behavior, according to the UTAUT model (Venkatesh et al., 2003). Therefore, facilitating conditions enable decisions to be taken in the behavioral roles of persons in information systems (Dwivedi, Rana, Chen \& Williams, 2011).

The mobile phone itself could be considered a facilitating factor, since $\mathrm{m}$-commerce is a voluntary activity performed to obtain specific benefits or services. A smartphone and a wireless network would allow this objective to be achieved easily when it comes to making purchases (Venkatesh et al., 2012). Indeed, it has been reported that facilitating conditions significantly influence the intention to use m-commerce and mobile applications (Blaise et al., 2018; Thakur \& Srivastava, 2013). Facilitating conditions also directly influence behavioral intention where consumers have a mobile phone with the Internet connection, a direct interface to explore mobile sites, and adequate knowledge to make purchases (Yang \& Forney, 2013). Therefore, the following hypothesis has been proposed:

H5: Facilitating conditions positively influence $\mathrm{m}$-commerce usage intention.

\section{Hedonic motivation}

Hedonic motivation is an intrinsic motivation that referring to the enjoyment a consumer derives from using a technology (Venkatesh et al., 2012). Theoretically, hedonic motivation has been described as an influential variable in the intention to adopt technology in information systems (Venkatesh et al., 2012). A direct impact of hedonic motivation on the intention to use technology has also been demonstrated (Venkatesh et al., 2012). Hedonic motivation also acts as a motivation for creativity and innovativeness in the context of mobile channels, stimulating their use (Assarut \& Eiamkanchanalai, 2015; van der Heijden, 2004). Applying the UTAUT2 model to the $\mathrm{m}$-commerce context, Madan and Yadav (2018) and Shaw and Sergueeva (2019) concluded that hedonic motivation has a significant impact on the intention to adopt m-commerce. In this regard, in a study seeking to explain mobile user engagement, Kim, Kim, and Wachter (2013) found that the hedonic motivation of consumers, namely the "fun and excitement" aspect, positively influences satisfaction with and engagement in the use of the smartphone. Extending this argument, it could be concluded that a consumer who enjoys using a mobile device for shopping will be more engaged in the activity and, therefore, more likely to use their device for shopping. Thus, hedonic motivation in the context of $\mathrm{m}$-commerce is expected to be a strong determinant; when users perceive entertainment in the functions of mobile shopping, they are more prone to adopt and use mobile shopping (Madan \& Yadav, 2018; Yang \& Forney, 2013). Hence, it follows that:

H6: Hedonic motivation positively influences $\mathrm{m}$-commerce usage intention.

In conclusion, the proposed research model (see Figure 1) suggests that the intention to use a mobile device for shopping depends on perceived usefulness, perceived ease of use, social influence, facilitating conditions, and hedonic motivation. 
FIGURE 1: Research model of m-commerce usage

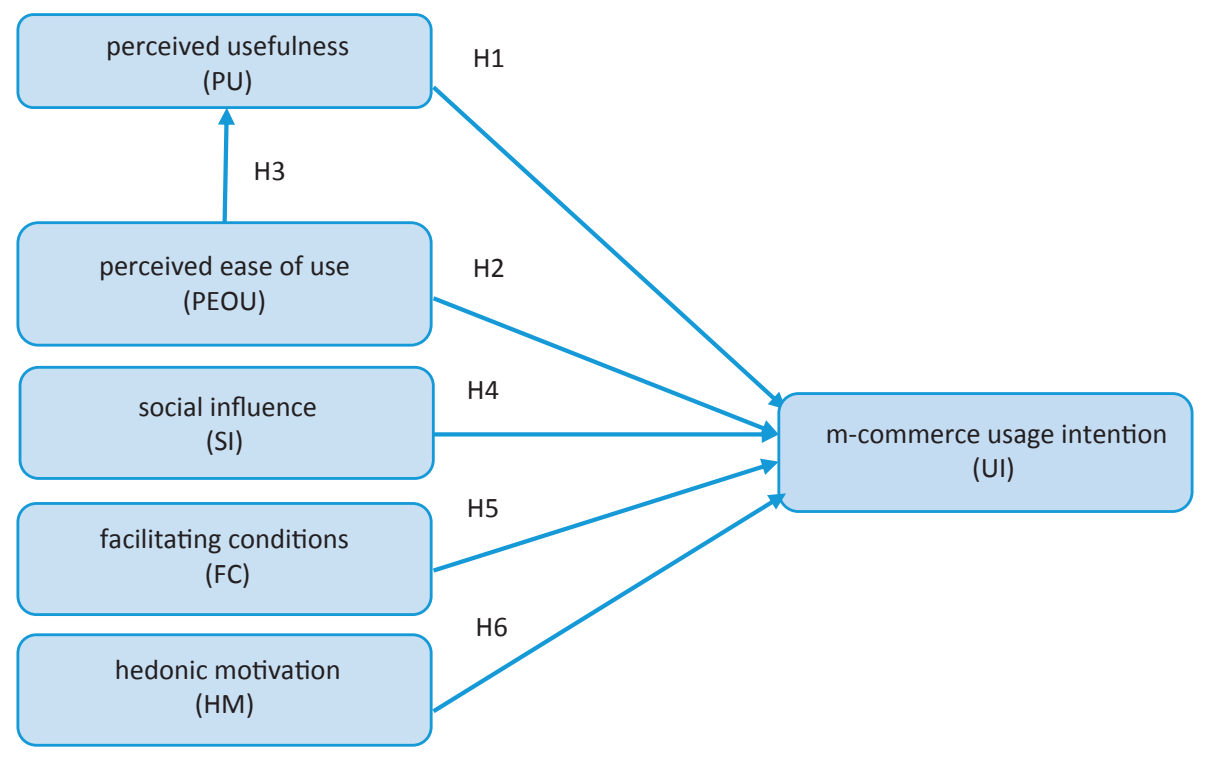

\section{METHODOLOGY}

The constructs studied in this research were measured based on existing literature in order to guarantee the validity of content (see Appendix). All the items were measured using a 5-point Likert-type scales, where 1 = "strongly disagree" and 5 = "strongly agree". Some items were adapted to the $\mathrm{m}$-commerce context. The instrument was pre-tested on ten students in the area of interest, giving rise to slight modifications in the wording of certain items.

The data were collected through a survey among undergraduate and postgraduate students of an Ecuadorian university, who came from both urban and rural areas. University student surveys are standard practice in marketing research. This population was also considered to be of interest for the purposes of this study because university students are one of the most important markets for m-commerce (Choi, Hwang \& McMillan, 2008; Jurisic \& Azevedo, 2011). Moreover, in Ecuador, the highest rate of smartphone possession is found among persons aged between 16 and 24 years (63.2\%) and 25 and 34 years (70.2\%), with Internet use being greater in urban areas and educational institutions (INEC, 2018).

The fieldwork was carried out during the months of June and July 2019. One of the researchers visited several classes and invited the students to answer the questionnaire using the link posted on his Facebook page. The students were informed about the main objective of the study, and the ethics of data collection and analysis. Of the 271 students contacted, 254 responded to the invitation. The final useful sample included 169 individuals who met the requirement of mobile technology use for shopping, established as a filter question.

With regard to the socio-demographic profile of respondents, the sample consisted of $61.5 \%$ women and $38.5 \%$ men, of whom $53.3 \%$ were between 18 and 24 years old, 27.2\% between 25 and 34 years old, $16.6 \%$ between 35 and 44 years old, and $3 \%$ over 45 years old. In terms of income, $63.3 \%$ of respondents had between USD 394 and USD 500 in monthly income, 16\% between USD 501 and USD 700, 8.9\% between USD 701 and USD 900, and 11.8\% over USD 900. 
The socio-demographic profile shows a higher percentage of older respondents than the average student profile because the questionnaire was answered not only by undergraduate students, but also by executives taking post-graduate programs as part-time students.

The partial least squares structural equation modeling (PLS-SEM) method was used to evaluate the model using the SmartPLS software. PLS is a particularly suitable approach in marketing research for the study of causal models with constructs that have multiple indicators and dimensions (Hair, Hult, Ringle \& Sarstedt, 2016).

\section{RESULTS}

SmartPLS software was used, firstly, to estimate the measurement model and evaluate the reliability and validity of the measurement constructs (see Table 2). All item loadings in the corresponding constructs were greater than 0.7 (Henseler, Ringle \& Sinkovics, 2009). Cronbach's alpha value for all the constructs exceeded the cut-off level of 0.70 (Nunnally, 1978), or, in the case of the social influence variable, was very close to reaching it (0.68). Composite reliability was higher than 0.8 and average variance extracted (AVE) exceeded 0.6 for every construct (Henseler et al., 2009).

TABLE 2: Construct reliability and validity

\begin{tabular}{|c|c|c|c|}
\hline Construct & $\begin{array}{l}\text { Cron- } \\
\text { bach's } \\
\text { alpha }\end{array}$ & $\begin{array}{l}\text { Com- } \\
\text { posite } \\
\text { reli- } \\
\text { ability }\end{array}$ & $\begin{array}{l}\text { Average } \\
\text { variance } \\
\text { extract- } \\
\text { ed (AVE) }\end{array}$ \\
\hline $\begin{array}{l}\text { Perceived } \\
\text { usefulness (PU) }\end{array}$ & 0.864 & 0.907 & 0.710 \\
\hline $\begin{array}{l}\text { Perceived ease of } \\
\text { use (PEOU) }\end{array}$ & 0.849 & 0.898 & 0.689 \\
\hline Social influence (SI) & 0.683 & 0.817 & 0.605 \\
\hline $\begin{array}{l}\text { Facilitating } \\
\text { conditions (FC) }\end{array}$ & 0.763 & 0.858 & 0.671 \\
\hline $\begin{array}{l}\text { Hedonic motivation } \\
(\mathrm{HM})\end{array}$ & 0.937 & 0.959 & 0.888 \\
\hline Usage intention (UI) & 0.895 & 0.923 & 0.705 \\
\hline
\end{tabular}

Following Henseler, Ringle and Sarstedt (2015), we evaluated discriminant validity according to the heterotrait and monotrait (HTMT) correlations, which are more sensitive than the Fornell-Larcker criterion. Therefore, we calculated the HTMT ratio for the correlations and cross-correlations between constructs (see Table 3 ). We took 5,000 sub-samples and observed the confidence intervals. Since $0.85 \%$ of the HTMT ratio was not exceeded, discriminant validity was confirmed (Hair, Ringle \& Sarstedt, 2011).

TABLE 3: HTMT ratio of correlations

\begin{tabular}{|l|c|c|c|c|c|c|}
\hline & PU & PEOU & SI & FC & HM & UI \\
\hline PU & & & & & & \\
\hline PEOU & 0.718 & & & & & \\
\hline SI & 0.150 & 0.262 & & & & \\
\hline FC & 0.599 & 0.807 & 0.310 & & & \\
\hline HM & 0.442 & 0.587 & 0.275 & 0.669 & & \\
\hline UI & 0.467 & 0.493 & 0.369 & 0.658 & 0.706 & \\
\hline
\end{tabular}

Table 4 contains the results of the structural model test, in which the path coefficients, the t-test, the $R^{2}$ value, and predictive relevance $\mathrm{Q}^{2}$ were examined. The hypotheses were contrasted by verifying the level of significance of the path coefficients (p) between the latent variables and the dependent variables. Social influence, facilitating conditions, and hedonic motivation accounted for $51.9 \%$ of the intention to use a mobile phone to purchase products and services. Of the six relationships analyzed, four were found to be significant for $p<0.05$. Perceived ease of use was significantly and positively related to perceived usefulness ( $\beta=0.645$, $p=0.000$ ). Therefore, H3 was accepted. Similarly, social influence was positively related to usage intention ( $\beta=0.141, p=0.009$ ), hence $\mathrm{H} 4$ was accepted. Since the relationship between facilitating conditions and usage intention was significant ( $\beta=0.312, p=0.001)$, H5 was also accepted. Similarly, H6 was accepted because the relationship between hedonic motivation and usage intention was positive and significant $(\beta=0.438, p=0.000)$. 
However, no significant relationship was observed between perceived ease of use and the intention to use a mobile phone for shopping $(H 1)$, nor was the relationship between per- ceived usefulness and usage intention significant for $p<0.01$ ( $\beta=0.156, p=0.065$ ), although it was likely to be significant for $p<0.1(\mathrm{H} 2)$.

TABLE 4: Significance of model paths

\begin{tabular}{|c|l|c|c|c|c|}
\hline $\begin{array}{c}\text { Hypo- } \\
\text { thesis }\end{array}$ & \multicolumn{1}{|c|}{ Path } & $\begin{array}{c}\text { Original } \\
\text { sample } \\
(\mathbf{O})\end{array}$ & $\begin{array}{c}\text { T statistic } \\
\text { (O/STER R) }\end{array}$ & P-value & $\begin{array}{c}\text { Signifi- } \\
\text { cance }\end{array}$ \\
\hline H1 & perceived usefulness -> usage intention & 0.156 & 1.843 & 0.065 & \\
\hline H2 & perceived ease of use -> usage intention & -0.131 & 1.103 & 0.270 & \\
\hline H3 & perceived ease of use -> perceived usefulness & 0.645 & 10.979 & 0.000 & $* * *$ \\
\hline H4 & social influence -> usage intention & 0.141 & 2.606 & 0.009 & $* *$ \\
\hline H5 & facilitating conditions -> usage intention & 0.312 & 3.358 & 0.001 & $* * *$ \\
\hline H6 & hedonic motivation -> usage intention & 0.438 & 5.697 & 0.000 & $* * *$ \\
\hline
\end{tabular}

$R^{2}$ (usage intention) $=0.519 ; R^{2}$ (perceived usefulness) $=0.417$

$\mathrm{Q}^{2}$ (usage intention) $=0.327 ; \mathrm{Q}^{2}$ (perceived usefulness) $=0.269$

*** $p<0.01 ;{ }^{* *} p<0.05$

\section{DISCUSSION AND CONCLUSION}

This paper contributes to the literature on m-commerce based on TAMs while offering practical knowledge that may be used by companies in developing countries to improve mobile channel adoption. Studies on the adoption of $\mathrm{m}$-commerce in developing countries are still limited and need to be further elaborated in a context of high growth rates and changing consumer behavior (Euromonitor, 2020). This study tested a model based on TAM and UTAUT2 to explain m-commerce usage intention in Ecuador. The results showed that social influence, facilitating conditions, and hedonic motivation play an important role in the intention to use $\mathrm{m}$-commerce. An interesting result of this study was that perceived ease of use and perceived usefulness were not significantly related with the intention to use m-commerce. This finding does not confirm the TAM postulates accepted in previous $\mathrm{m}$-commerce studies (Choi, 2018; Faqih \& Jaradat, 2015; Venkatesh et al., 2003). However, findings concerning the impact of usefulness have been mixed; some authors found that the relationship between perceived usefulness and perceived ease of use and the intention to adopt m-commerce was non-significant in the Chinese market (Chong, 2013; Chong et al., 2012). The non-acceptance of the hypotheses concerning the key variables of the TAM model ( $\mathrm{H} 1$ and $\mathrm{H} 2$ ) can be explained by rapid technological change and the fact that smartphones are increasingly popular among young people who use them to interact on social media in their free time (Chong, 2013). Thus, in the context of a developing country such as Ecuador, where m-commerce has exploded following a surge in smartphone possession rates, ease of use and perceived usefulness are not relevant. A later adoption of m-commerce would imply advances in smartphone capabilities and improvements made by companies to their mobile channel interface.

Social influence was one of the factors shown to positively influence the usage of $\mathrm{m}$-commerce. This finding is consistent with the results published in previous studies and highlights the strong influence of family and groups of friends on the adoption of $\mathrm{m}$-commerce in developing markets (Verkijika, 2018; Wei et al., 2009; Yadav et al., 2016). Our results showed that young people are likely to be influenced by their social 
circle when it comes to a preference for m-commerce. Facilitating conditions also had a significant influence on the use of $\mathrm{m}$-commerce. This confirms the limited evidence of the influence of this variable in developing markets (Madan \& Yadav, 2018; Verkijika, 2018). Thus, m-commerce should expand as Internet access conditions improve and individuals acquire the necessary resources and support. Finally, the results revealed that the factor with the strongest positive impact on $\mathrm{m}$-commerce usage intention is hedonic motivation, as reported in the small number of studies that have tested this variable in developing markets (Madan \& Yadav, 2018; Verkijika, 2018). Together with the reference to social influence, this result confirms that mobile shopping is associated with leisure and enjoyment rather than with usefulness. Therefore, the main contribution of this paper is in showing empirically that, in a developing market, when the TAM model is expanded by including variables of the UTAUT2 model relating more specifically to the mobile technology, the influence of the ease-of-use and usefulness variables is not significant, while social influence, facilitating conditions, and hedonic motivation are revelant.

The results of this paper present interesting management implications. Since hedonic motivation is the variable with the most substantial influence on the intention to use m-commerce, online marketers should focus their efforts on developing interfaces that convey pleasant and stimulating sensations rather than those suggesting routine or obligation. Humor and games could even be used to engage more directly with that enjoyment-driven motivation when using a mobile phone for shopping. Thus, companies could benefit from communicating the fun aspects associated with using their mobile solutions. However, online sellers should not forget that mobile shopping also requires facilitating conditions. Companies should focus on developing user-friendly interfaces that allow for easy text reading, a clear view of products, and fast loading of photographs. As outlined by Madan and Yadav (2016), older consumers may need additional assistance and support to facilitate the use of the mobile channel for shopping.
The results also showed that social influence is positively related to the intention to use a smartphone for online shopping. Online sellers should be aware that the social groups their consumers are interacting with exert a certain amount of social pressure for those consumers to behave in a particular way. Companies could use images reflecting social interaction in their communications, as well as encourage m-commerce recommendation actions through, for example, promotions or discounts. Online sellers could leverage their customers' social media usage, encouraging them to share their experiences and post product reviews.

This study is not without limitations. The data were collected in Ecuador, a country in which mobile shopping is in its initial stage. Although the interest in the data reported stems partly from the fact that these were obtained in a developing country with a high potential for m-commerce, future research could focus on the respondents in other developing and emerging countries. Our sample was recruited among undergraduate and postgraduate university students. The results of this study should be interpreted bearing in mind that smartphone usage is more common among younger and more educated adults in developing countries (INEC, 2018).

The fact that the study's expectations regarding the influence of perceived ease of use and perceived usefulness variables on mobile shopping intention were not fulfilled opens up opportunities for further research to corroborate the significance of the key variables of the TAM model by using a model to explore m-commerce in developing markets with high growth rates. Another possible line of research is to investigate the influence of other variables such as trust or perceived risk in $\mathrm{m}$-commerce usage in developing markets.

\section{Acknowledgment}

This work was supported by the Spanish Ministry of Science, Innovation and Universities, Spanish State Research Agency under Grant ECO 2017-83051-R. 


\section{References}

1. Ajzen, I. (1991). The theory of planned behavior. Organizational Behavior and Human Decision Processes, 50(2), 179-211.

2. Alalwan, A. A., Dwivedi, Y. K., Rana, N. P., Lal, B., \& Williams, M. D. (2015). Consumer adoption of Internet banking in Jordan: Examining the role of hedonic motivation, habit, self-efficacy and trust. Journal of Financial Services Marketing, 20(2), 145-157.

3. Andrews, M., Goehring, J., Hui, S., Pancras, J., \& Thornswood, L. (2016). Mobile promotions: A framework and research priorities. Journal of Interactive Marketing, 34, 15-24.

4. Anwar, A., Thongpapanl, N., \& Ashraf, A. R. (2020). Strategic imperatives of mobile commerce in developing countries: the influence of consumer innovativeness, ubiquity, perceived value, risk, and cost on usage. Journal of Strategic Marketing, doi: 10.1080/0965254X.2020.1786847

5. Aslam, W., Ham, M., \& Arif, I. (2017). Consumer Behavioral Intentions Towards Mobile Payment Services: an Empirical Analysis in Pakistan. Market, 29(2), 161-176.

6. Assarut, R., \& Eiamkanchanalai, S. (2015). Consumption values, personal characteristics and behavioral intentions in mobile shopping adoption. Market, 27(1), 21-41.

7. Bhatti, T. (2007). Exploring factors influencing the adoption of mobile commerce. Journal of Internet Banking and Commerce, 12(3), 1-13.

8. Blaise, R., Halloran, M., \& Muchnick, M. (2018). Mobile commerce competitive advantage: A quantitative study of variables that predict m-commerce purchase intentions. Journal of Internet Commerce, 17(2), 96-114.

9. Chhonker, M. S., Verma, D., \& Kar, A. K. (2017). Review of technology adoption frameworks in mobile commerce. Procedia Computer Science, 122, 888-895.

10. Choi, S. (2018). What promotes smartphone-based mobile commerce? Mobile-specific and self-service characteristics. Internet Research, 28(1), 105-122.

11. Choi, Y. K., Hwang, J., \& McMillan, S. J. (2008). Gearing up for mobile advertising: a cross-cultural examination of key factors that drive mobile messages home to consumers. Psychology and Marketing, 25(8), 756-768.

12. Chong, A. Y.-L. (2013). A two-staged SEM-neural network approach for understanding and predicting the determinants of m-commerce adoption. Expert Systems with Applications, 40(4), 1240-1247.

13. Chong, A. Y.-L., Chan, F. T. S., \& Ooi, K.-B. (2012). Predicting consumer decisions to adopt mobile commerce: Cross country empirical examination between China and Malaysia. Decision Support Systems, 53(1), 34-43.

14. Davis, F. D. (1989). Perceived usefulness, perceived ease of use, and user acceptance of information technology. MIS Quarterly, 13(3), 319-340.

15. Davis, F. D., Bagozzi, R. P., \& Warshaw, P. R. (1989). User acceptance of computer technology: A comparison of two theoretical models. Management Science, 35(8), 982-1003.

16. Dwivedi, Y. K., Rana, N. P., Chen, H., \& Williams, M. D. (2011). A Meta-analysis of the Unified Theory of Acceptance and Use of Technology (UTAUT). In M. N. A. G. K. K. I. S. N. Blinn (Ed.), Governance and Sustainability in Information Systems. Managing the Transfer and Diffusion of IT: IFIP WG 8.6 International Working Conference (pp. 155-170). London: Springer.

17. eMarketer (2019). Latin America e-commerce 2019. Retrieved from https://www.emarketer.com/ content/latin-america-ecommerce-2019

18. Euromonitor (2020). Mobile e-commerce in Ecuador. Retrieved from https://www.portal.euromonitor.com/portal/Analysis/Tab

19. Faqih, K. M., \& Jaradat, M. I. R. M. (2015). Assessing the moderating effect of gender differences and individualism-collectivism at individual-level on the adoption of mobile commerce technology: TAM3 perspective. Journal of Retailing and Consumer Services, 22, 37-52. 
20. Hair, J. F., Ringle, C. M., \& Sarstedt, M. (2011). PLS-SEM: Indeed a silver bullet. Journal of Marketing Theory and Practice, 19(2), 139-151.

21. Hair, J., Hult, T., Ringle, C., \& Sarstedt, M. (2016). A primer on partial least squares structural equation modeling (PLS-SEM). LOS Angeles: SAGE.

22. Henseler, J., Ringle, C. M., \& Sarstedt, M. (2015). A new criterion for assessing discriminant validity in variance-based structural equation modeling. Journal of the Academy of Marketing Science, 43(1), 115-135.

23. Henseler, J., Ringle, C. M., \& Sinkovics, R. R. (2009). The use of partial least squares path modeling in international marketing. Advances in International Marketing, 20, 277-319.

24. INEC. (2018). Instituto nacional de estadisticas y censos, Ecuador.

25. Jiménez, N., San-Martin, S., \& Azuela, J. I. (2016). Trust and satisfaction: the keys to client loyalty in mobile commerce. Academia Revista Latinoamericana de Administración, 29(4), 485-510.

26. Jurisic, B., \& Azevedo, A. (2011). Building customer-brand relationships in the mobile communications market: The role of brand tribalism and brand reputation. Journal of Brand Management, 18(4), 349-366.

27. Kim, H.-W., Chan, H. C., \& Gupta, S. (2007). Value-based adoption of mobile internet: An empirical investigation. Decision Support Systems, 43(1), 111-126.

28. Kim, Y. H., Kim, D. J., \& Wachter, K. (2013). A study of mobile user engagement (MoEN): Engagement motivations, perceived value, satisfaction, and continued engagement intention. Decision Support Systems, 56, 361-370.

29. Kleijnen, M., de Ruyter, K., \& Wetzels, M. (2007). An assessment of value creation in mobile service delivery and the moderating role of time consciousness. Journal of Retailing, 83(1), 33-46.

30. Larivière, B., Joosten, H., Malthouse, E. C., van Birgelen, M., Aksoy, P., Kunz, W. H., \& Huang, M. (2013). Value fusion: The blending of consumer and firm value in the distinct context of mobile technologies and social media. Journal of Service Management, 24(3), 268-293.

31. Lu, J. (2014). Are personal innovativeness and social influence critical to continue with mobile commerce? Internet Research, 24(2), 134-159.

32. Madan, K., \& Yadav, R. (2018). Understanding and predicting antecedents of mobile shopping adoption. Asia Pacific Journal of Marketing and Logistics, 30(1), 139-162.

33. Marinao-Artigas, E., \& Barajas-Portas, K. (2020). Precedents of the satisfaction of mobile shoppers. A cross-country analysis. Electronic Commerce Research and Applications, 39(1), 100919.

34. Marinkovic, V., \& Kalinic, Z. (2017). Antecedents of customer satisfaction in mobile commerce. Online Information Review, 41(2), 138-154.

35. Ntsafack Dongmo, F.W., Kala Damdjoug, J.R, \& Fosso Wamba, S. (2020). Mobile Commerce Adoption in a Developing Country: Driving Factors in the Case of Cameroon. In ICT for an Inclusive World (pp. 275-288). Cham: Springer.

36. Nunnally, J. C. (1978). Psychometric theory. New York, NY: McGraw-Hill.

37. Okazaki, S. (2005). New perspectives on m-commerce research. Journal of Electronic Commerce Research, 6(3), 160-164.

38. PwC. (2019). Global consumer insights survey 2019: It's time for a consumer-centred metric: Introducing 'return on experience.' Retrieved from https://www.pwc.com/ee/et/publications/pub/Consumer-Insight-Survey-2019-report.pdf

39. Rogers, E. (1983). Diffusion of innovations. New York, NY: The Free Press.

40. Shankar, V., Kleijnen, M., Ramanathan, S., Rizley, R., Holland, S., \& Morrissey, S. (2016). Mobile shopper marketing: Key issues, current insights, and future research avenues. Journal of Interactive Marketing, 34, 37-48. 
41. Shankar, V., Venkatesh, A., Hofacker, C., \& Naik, P. (2010). Mobile marketing in the retailing environment: Current insights and future research avenues. Journal of Interactive Marketing, 24(2), $111-120$.

42. Shaw, N., \& Sergueeva, K. (2019). The non-monetary benefits of mobile commerce: Extending UTAUT2 with perceived value. International Journal of Information Management, 45, 44-55.

43. Ström, R., Vendel, M., \& Bredican, J. (2014). Mobile marketing: A literature review on its value for consumers and retailers. Journal of Retailing and Consumer Services, 21(6), 1001-1012.

44. Tarhini, A., Alalwan, A. A., Shammout, A. B., \& Al-Badi, A. (2019). An analysis of the factors affecting mobile commerce adoption in developing countries. Review of International Business and Strategy, 29(3), 157-179.

45. Thakur, R., \& Srivastava, M. (2013). Customer usage intention of mobile commerce in India: an empirical study. Journal of Indian Business Research, 5(1), 52-72.

46. van der Heijden, H. (2004). User acceptance of hedonic information systems. MIS Quarterly, 28(4), 695-704.

47. Venkatesh, V. (2000). Determinants of perceived ease of use: Integrating control, intrinsic motivation, and emotion into the technology acceptance model. Information Systems Research, 11(4), 342-365.

48. Venkatesh, V., Morris, M. G., Davis, G. B., \& Davis, F. D. (2003). User acceptance of information technology: Toward a unified view. MIS Quarterly, 27(3), 425-478.

49. Venkatesh, V., Thong, J. Y. L., \& Xu, X. (2012). Consumer acceptance and use of information technology: Extending the unified theory of acceptance and use of technology. MIS Quarterly, 36(1), 157-178.

50. Verkijika, S. F. (2018). Factors influencing the adoption of mobile commerce applications in Cameroon. Telematics and Informatics, 35(6), 1665-1674.

51. Wang, H.-Y., \& Wang, S.-H. (2010). User acceptance of mobile internet based on the unified theory of acceptance and use of technology: Investigating the determinants and gender differences. Social Behavior and Personality: An International Journal, 38(3), 415-426.

52. Wang, R. J-H., Malthouse, E. C., \& Krishnamurthi, L. (2015). On the go: How mobile shopping affects customer purchase behavior. Journal of Retailing, 91(2), 217-234.

53. Wei, T.T., Marthandan, G., Chong, A.Y.L., Ooi, K.B, \& Arumugam, S. (2009). What drives Malaysian m-commerce adoption? An empirical analysis. Industrial Management \& Data Systems, 109(3), 370-388.

54. Yadav, R., Sharma, S. K., \& Tarhini, A. (2016). A multi-analytical approach to understand and predict the mobile commerce adoption. Journal of Enterprise Information Management, 29(2), 222-237.

55. Yang, K. (2010). Determinants of US consumer mobile shopping services adoption: Implications for designing mobile shopping services. Journal of Consumer Marketing, 27(3), 262-270.

56. Yang, K., \& Forney, J. C. (2013). The moderating role of consumer technology anxiety in mobile shopping adoption: Differential effects of facilitating conditions and social influences. Journal of Electronic Commerce Research, 14(4), 334-347.

57. Zhang, L., Zhu, J., \& Liu, Q. (2012). A meta-analysis of mobile commerce adoption and the moderating effect of culture. Computers in Human Behavior, 28(5), 1902-1911.

58. Zhang, R., Chen, J. Q., \& Lee, C. J. (2013). Mobile commerce and consumer privacy concerns. Journal of Computer Information Systems, 53(4), 31-38.

59. Zhou, T. (2013). An empirical examination of the determinants of mobile purchase. Personal and Ubiquitous Computing, 17(1), 187-195. 


\section{Appendix: Measurement scales}

Constructs/items

Perceived usefulness

Using the mobile phone to make purchases would be beneficial for me.

The advantages of using the mobile phone to make purchases outweigh its disadvantages.

In general, making purchases through the mobile phone is advantageous. Using the mobile phone would allow me to make my purchases faster.

\section{Perceived ease of use}

The way to use the mobile phone for purchases is clear and understandable.

Using the mobile phone for purchases does not require much mental

Choi (2018) effort.

It seems to me that it is easy to trade through the mobile phone.

One can easily make purchases using the mobile phone.

\section{Social influence}

My family and friends influence my decision to use my mobile phone to make purchases.

The media (television, radio, newspapers) influence my decision to use my mobile phone for purchases.

I think I would be more prepared to make purchases through the mobile phone if people from my social circle did.

\section{Facilitating conditions}

My mobile phone allows me to easily access shopping websites. Given the resources, opportunities, and knowledge necessary for purchases through the mobile phone, it would be easy for me to use such a system.

I have the knowledge necessary for purchases through the mobile phone.

\section{Hedonic motivation}

Using the mobile phone for purchases is fun.

I enjoy using the mobile phone when I have to buy something.

Using the mobile phone to make a purchase is very entertaining.

\section{Usage intention}

I believe that, in the future, my use of the mobile phone for purchases will increase.

I intend to use the mobile phone to buy things in the future.

I would recommend using the mobile phone for buying to my family or

Marinkovic \& Kalinic (2017) friends.

Whenever possible, I will try to use the mobile phone to make purchases.

I intend to frequently use the mobile phone to make purchases.

Yang (2010)

Venkatesh, Morris,

Davis \& Davis (2003) 